\title{
Marginal Microleakage of Newly Synthesized Nanostructured Biomaterials Based on Active Calcium Silicate Systems and Hydroxyapatite
}

\author{
Violeta Petrović ${ }^{1}$, Vanja Opačić Galić ${ }^{1}$, Bojan Dželetović1, Vukoman Jokanović ${ }^{\text {, Slavoljub Živković }}$ \\ 'University of Belgrade, Faculty of Dental Medicine, Department of Restorative Dentistry and Endodontics, Belgrade, \\ Serbia; \\ "Institute of Nuclear Sciences “Vinča”, University of Belgrade, Belgrade, Serbia
}

\begin{abstract}
SUMMARY
Introduction Calcium silicate cements can be successfully used for the treatment of root perforations due to their exceptional biological and sealing properties. The aim of this study was to test, using dye penetration method, marginal microleakage of newly synthesized nanostructured biomaterials based on calcium silicate system and hydroxyapatite after their application in interradicular perforation of extracted teeth.

Material and Methods The study included 34 extracted human molars. Newly synthesized nanostructured materials: one based on calcium silicate system (CS), and the other one based on hydroxyapatite and active calcium silicate system (HA-CS) were tested. Mineral trioxide agreaggate (MTA; Angelus, Londrina, Brazil) was used as control. Marginal microleakage was evaluated using dye penetration test 6 months after the application of materials in experimentally prepared inter-radicular perforations in extracted human molars. Dye penetration was analyzed using light microscope at 30X magnification, a method of quantifying visual information in computer software for image processing (Adobe Photoshop CS5 Extended, version $12.0 \times 32$ ). The values were expressed in millimeters, and the results statistically analyzed using one-way ANOVA and Tukey post-hoc test $(\alpha=0.05)$.

Results The shortest dye penetration was measured for calcium silicate system $(0.44 \mathrm{~mm})$, while slightly higher values were found for MTA $(0.54 \mathrm{~mm})$. Dye penetration for hydroxyapatite and active calcium silicate system $(2.00 \mathrm{~mm})$ was longer than for the other two materials $(p<0.05)$.

Conclusion The lowest marginal microleakage was observed in CS and was comparable to MTA. Microleakage in HA-CS was significantly higher than CS and MTA.

Keywords: marginal microleakage; calcium silicate cements; hydroxyapatite
\end{abstract}

\section{INTRODUCTION}

Marginal seal or adequate marginal adaptation of material along the cavity walls should be able to prevent leakage of tissue fluid and consequently bacterial microleakage. Therefore, it is considered as significant factor for longterm success of endodontic treatment [1].

Calcium silicate cements were introduced in endodontic practice in the mid 90-ies of the last century in order to be used as materials for closing root perforations and root apical closure after apical surgery. Studies have demonstrated superior marginal seal achieved by calcium silicate cements compared to amalgam and cements based on zinc-oxide-eugenol (ZOE; Super EBA and IRM cement), which have been commonly used in these indications [1]. It has also been demonstrated that calcium silicate cements achieve good marginal seal in cavities contaminated with blood [1,2], they are biocompatible [1], bioactive [3] and induce regeneration of hard dental $[4,5]$ and periodontal tissue [6]. Consequently, their indications have expanded significantly [7].

The main issue for clinical use of calcium silicate cements is their long setting time [8]. Initial binding of several hours increases the risk of material dissolution and leaching from the site of application. Moisture is needed for hydration and setting of these materials, which is why additional external moisture is needed during initial bonding. That inevitably delays completion of endodontic treatment [9]. In previous years, numerous studies have been conducted in order to overcome this problem [10-13].

Modern research has focused on synthesis and evaluation of new nanostructured biomaterials in similar endodontic indications [14]. Nanomaterials are characterized among others, by pronounced activity of particles and consequently, faster setting in comparison with conventional microstructural materials [15]. The Institute of Nuclear Sciences in Vinča, according to the recipe of Jokanović et al. [16], synthesized two new biomaterials: one based on calcium silicate system (CS) and the other one based on hydroxyapatite and active calcium silicate system (HA-CS). These materials showed initial setting of 10 minutes (CS) and 15 minutes (HA-CS), respectively. Previous studies have shown that these materials have less genotoxic and cytotoxic effects, but higher osteogenic potential than commercial calcium silicate cements $[17,18]$. 
The aim of this study was to test, using dye penetration method, marginal microleakage of newly synthesized nanostructured biomaterials based on calcium silicate system and hydroxyapatite (HA- CS) after their application in interradicular perforation of extracted teeth.

\section{MATERIAL AND METHODS}

Three materials in total were tested in this study: new material based on calcium silicate system (CS), new material based on mixtures of hydroxyapatite and calcium silicate system (HA-CS) and control material MTA (MTA Angelus ${ }^{\oplus}$,Londrina, Brazil). Experiments were performed on 34 human, extracted, maxillary and mandibular molars with fully developed and non-fused roots. Access cavities were prepared with high speed handpiece, which after hand K-files (K-files, VDW GmbH, Germany) were used to establish working length of root canals up to $1 \mathrm{~mm}$ shorter than the anatomy of the foramen. Root canals were instrumented with Crown-down technique using series of rotary files BioRace (FKG Dentaire, Swiss Dental Products, Switzerland). During instrumentation, canals were irrigated with $0.5 \% \mathrm{NaOCl}$. For the final rinse $5 \mathrm{~mL}$ of $10 \%$ citric acid solution (during $1 \mathrm{~min}$ ) and $5 \mathrm{~mL}$ of $0.5 \%$ sodium hypochlorite solution were used. After drying the canals were obturated using monocone technique and sealer Acroseal (Septodont, France).

After sealer setting, in the center of the pulp chamber floor, using slow speed handpiece and round bur size \# 4 inter-radicular perforations were prepared. The size of perforations was the same as diameter of round bur while the depth depended on the thickness of the pulp chamber floor. After washing perforations with distilled water and air-drying, the teeth were randomly assigned into the three experimental groups according to the materials used: CS, HA-CS and MTA $(n=10)$. Positive controls were teeth with perforations that were not sealed and negative controls were two teeth without perforations.

Prior to the application of the test material, the teeth were placed in a sponge soaked with artificial tissue fluid up to the level of enamel-cement junction (Eng. Hank's balanced salt solution, HBSS). Materials were mixed with distilled water in the ratio of 3:1 and placed in the prepared cavities using condensers. On the top of the material a moist cotton pellet was placed and the teeth were incubated at $37^{\circ} \mathrm{C}$ for $24 \mathrm{~h}$. After complete setting of materials access cavities were permanently closed using composite. Teeth were incubated in sponges at $37^{\circ} \mathrm{C}$ for the next 6 months.

After 6 months marginal microleakage was evaluated using passive dye penetration method. The teeth were coated with two coats of varnish, except in the area of the material in the furcation (about $1 \mathrm{~mm}$ around material) and placed in $50 \%$ solution of silver nitrate $\left(\mathrm{AgNO}_{3}\right)$ for 2 h. After quick rinsing teeth were immersed in photo developer for $6 \mathrm{~h}$. Teeth were cut longitudinally in the region of perforation using diamond disc of $0.7 \mathrm{~mm}$ thickness and linear speed saw with water cooling (Isomet testers 4000, Buehler, Lake Bluff, IL, USA). Dye penetration between the material and cavity walls was analyzed using light microscopy and photographed at 30X magnification. The depth of dye penetration was measured using the method of quantifying of visual information in computer software for image processing (Adobe Photoshop CS5 Extended, version $12.0 \times 32$ ). The obtained values were expressed in millimeters. The results were statistically analyzed using one-way ANOVA with Tukey post-hoc test. The level of significance was set at $\alpha=0.05$

\section{RESULTS}

The shortest dye penetration was found for CS $(0.44 \pm 0.54$ $\mathrm{mm}$ ) (Figure 1). Similar values were measured for MTA $(0.54 \pm 0.76 \mathrm{~mm})$ (Figure 2). The longest dye penetration was recorded for HA-CS $(2.00 \pm 0.70 \mathrm{~mm})$ (Graph 1, Figure 3 ). There was no statistically significant difference in marginal dye penetration between CS and MTA. HA-CS showed dye penetration that was significantly longer than for CS and MTA $(\mathrm{p}<0.05)$.

In addition to color penetration between restorations and dentin, staining of tested materials was also noticed (Figures 4, 5 and 6).

\section{DISCUSSION}

Dye or bacteria penetration or fluid filtration methods are most commonly used for the evaluation of marginal microleakage of different materials in vitro [19-22]. In the current study dye penetration method was used due to simplicity as described in numerous studies $[19,20$, $23,24,25]$. One of the main objections to dye penetration method is related to the size of dye molecules that are commonly used which are actually smaller than the size of bacteria [19]. Therefore, for materials that show penetration of small dye molecules, it can be expected that leakage of larger molecules (bacteria and their products) will be absent [1].

When choosing dye for the assessment of marginal leakage chemical nature of the tested material should be taken into account. Wu et al. [26] found that methylene blue is unstable in the presence of alkaline substances resulting in its decolorization. As calcium hydroxide is major ingredient of MTA, the use of methylene blue for

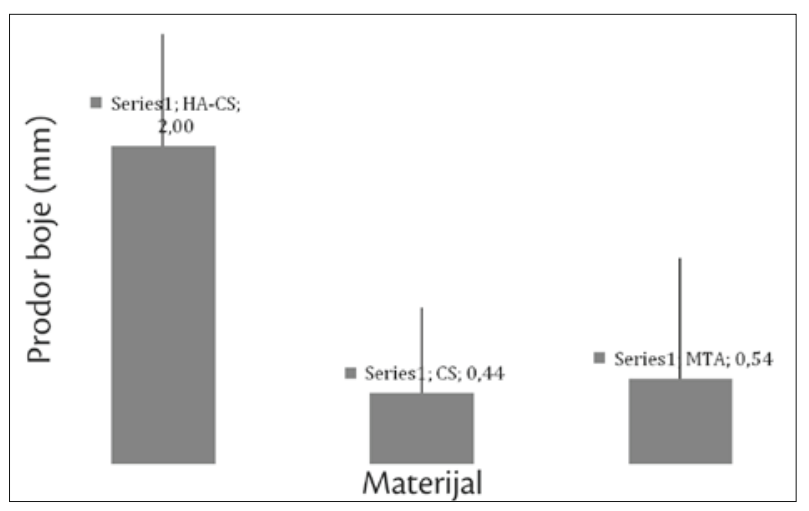

Graph 1. Average microleakage of the tested materials Grafikon 1. Srednje vrednosti prodora boje ispitivanih materijala 


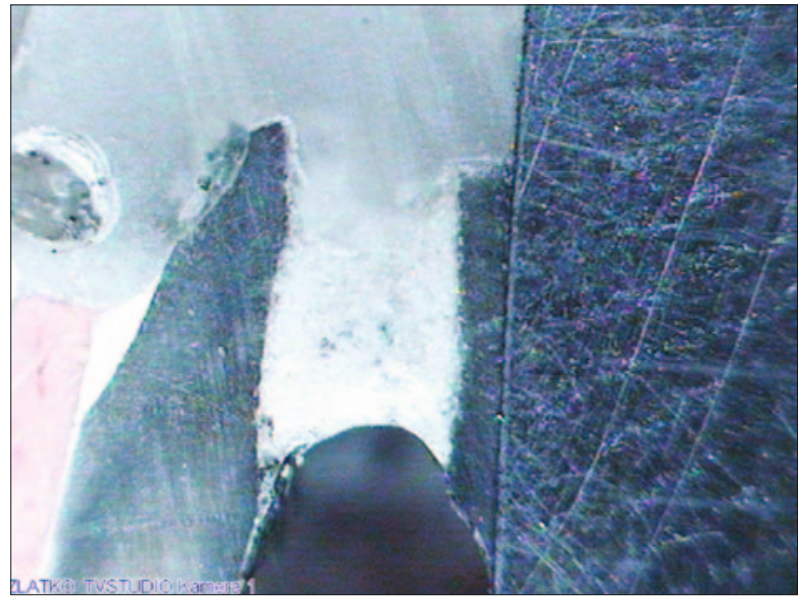

Figure 1. Inter-radicular perforation filled with calcium silicate material. There is no dye marginal leakage $(\times 30)$.

Slika 1. Interradiksna perforacija ispunjena kalcijumsilikatnim materijalom. Ne uočava se marginalni prodor boje $(\times 30)$.

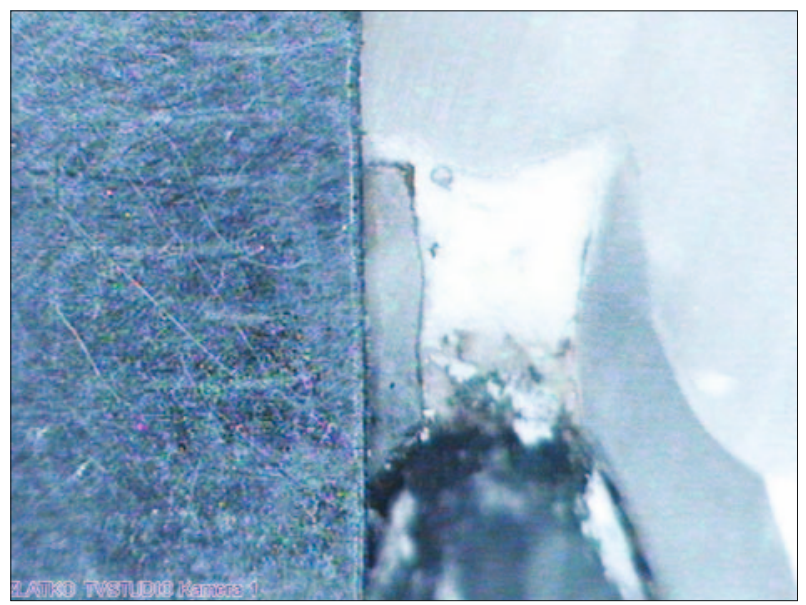

Figure 3. Inter-radicular perforation filled with hydroxyapatite-calcium silicate material. There is dye marginal leakage and absorption with material color change $(\times 30)$.

Slika 3. Interradiksna perforacija ispunjena materijalom hidroksiapatitom i kalcijumsilikatnim cementom. Uočavaju se prodor i apsorpcija boje sa delimičnim prebojavanjem materijala $(\times 30)$.

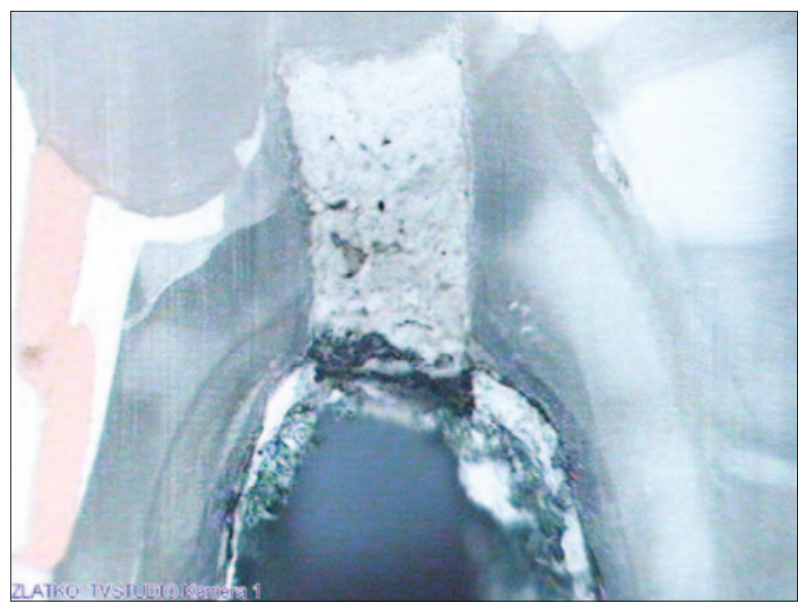

Figure 5. Inter-radicular perforation filled with hydroxyapatite-calcium silicate material. There is dye absorption with most of material having changed color $(\times 30)$.

Slika 5. Interradiksna perforacija ispunjena materijalom hidroksiapatitom i kalcijumsilikatnim cementom. Uočava se apsorpcija boje sa prebojavanjem većeg dela materijala $(\times 30)$.

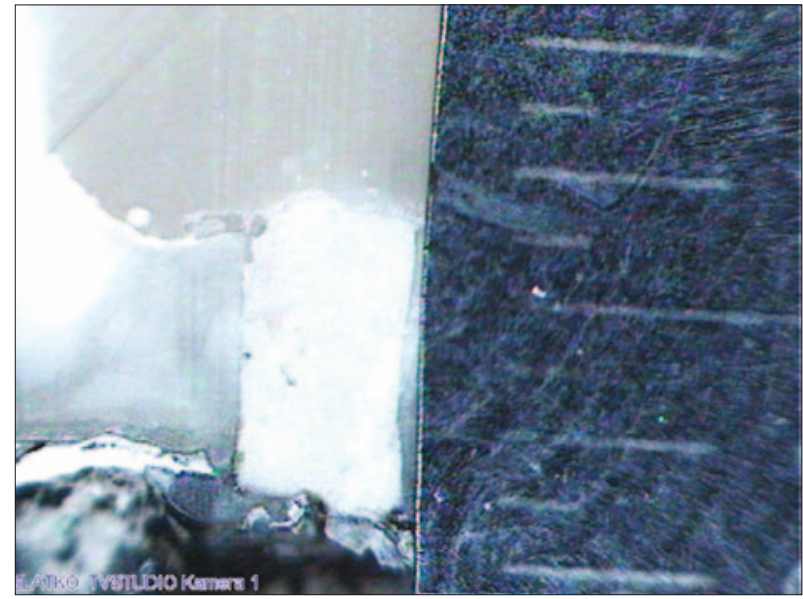

Figure 2. Inter-radicular perforation filled with MTA. There is no dye marginal leakage $(\times 30)$.

Slika 2. Intreradiksna perforacija ispunjena materijalom MTA. Ne uočava se marginalni prodor boje $(\times 30)$.

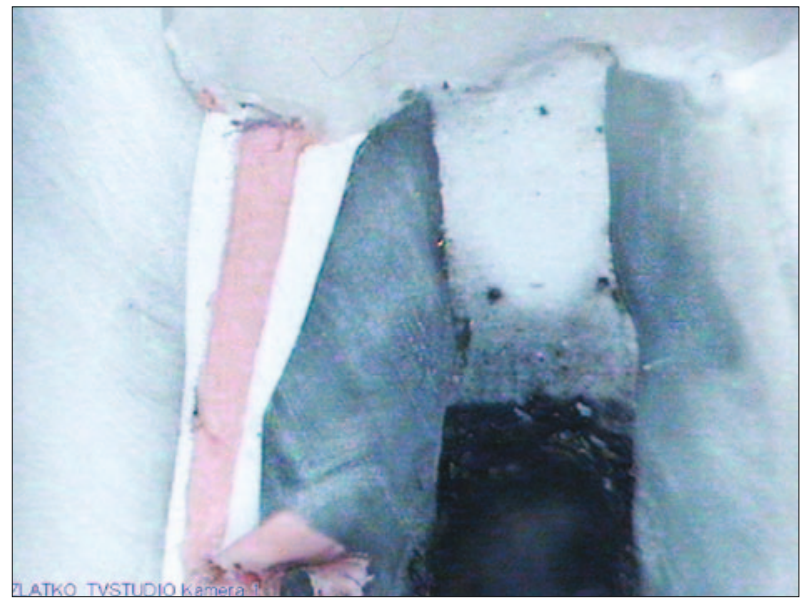

Figure 4. Inter-radicular perforation filled with calcium silicate material. There is dye marginal leakage and absorption with material color change $(\times 30)$.

Slika 4. Interradiksna perforacija ispunjena kalcijumsilikatnim materijalom. Uočava se prodor i apsorpcija boje sa delimičnim prebojavanjem materijala $(\times 30)$.

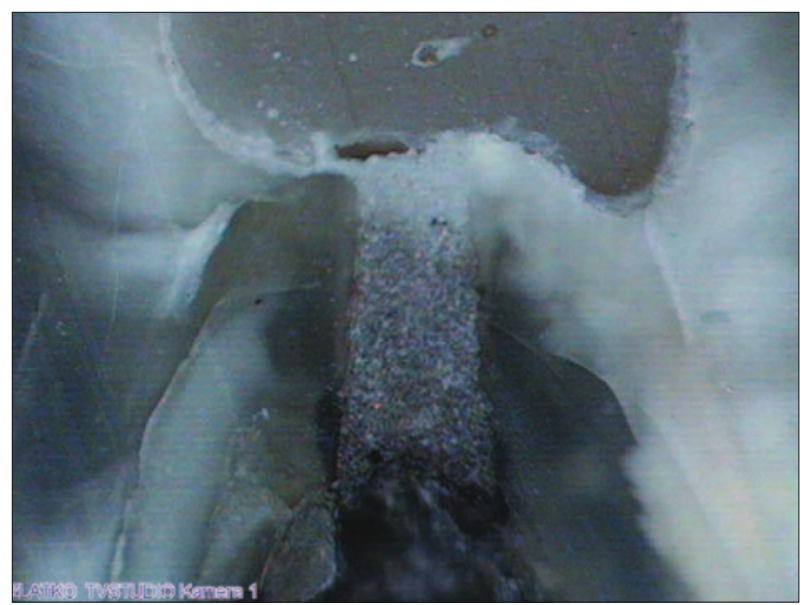

Figure 6. Inter-radicular perforation filled with MTA. There is dye absorption and color change throughout the whole thickness of material $(\times 30)$.

Slika 6. Interradiksna perforacija ispunjena materijalom MTA. Uočavaju se prodor i apsorpcija boje celom debljinom materijala $(\times 30)$. 
the evaluation of MTA and other materials of similar composition would cause its discoloration and eventually unreliable results. A solution of silver nitrate was chosen as dye due to its stability in the presence of the high $\mathrm{pH}$ and high molecular weight of silver particles [25].

Marginal microleakage was assessed after the application of the test material in experimentally prepared, inter-radicular perforations of extracted teeth. During the experimental period the teeth were stored in an incubator, with a sponge soaked in artificial tissue fluid to simulate clinical conditions [21]. In the current study, the deepest dye penetration was measured after the teeth were longitudinally cut. Therefore, it was not possible to determine precisely in which part of the cavity dye penetrated the most. Dye penetration method done in vitro cannot be directly related to the complex in vivo microleakage but it can be possible indicator of microleakage in clinical conditions [20].

The lowest dye penetration in the current study was observed for CS material. The values of dye penetration for MTA were slightly higher but with no statistically significant difference compared to CS. Given that CS and MTA have similar composition and physical properties are likely similar. Good marginal seal of calcium silicate cements is associated with mild expansion of cement during setting [27, 28], bio-activity and hydroxyapatite formation on the surface of the material in contact with phosphates from tissue fluids [29].

However, different microleakage evaluating methods have shown that MTA and similar calcium silicate cements do not have the ability of absolute hermetic sealing $[21,22,25,30]$, which is consistent with the results of the current study. In the group of samples with CS, the measured values of dye penetration were lower compared to the MTA samples, however, larger number of samples in the $\mathrm{CS}$ group showed microleakage than in the MTA group. The measured values of dye penetration in the MTA group were very different, and the results are consistent with the findings of De Deus et al. [30]. They evaluated the marginal microleakage of different calcium silicate cements (PC, MTA Angelus and MTA Bio) and reported very variable results within groups. They also detected microleakage in all samples but with no statistically significant difference between different calcium silicate cements [30]. In contrast, Hashem et al. [19] observed differences in the permeability of various commercial calcium silicates, considering that different chemical composition and different setting time may play a role in the material attachment to the cavity walls. Also, studies that evaluated permeability of calcium silicate cements using bacteria penetration method have reported different results. Montelano et al. [2] recorded the most pronounced microleakage in the first days of application of materials, while Parirokh et al. [21] detected significantly delayed bacterial penetration (between 39 and 73 days of experiment) highlighting the positive impact of phosphate solution on the adhesion of material.

Literature reviews describe inconsistency in results for the permeability of calcium silicate cements using different testing methods. Many factors influence microleakage of MTA: dye, $\mathrm{pH}$ of dye, storage conditions of samples before experiment, and setting time of material prior to immersion of samples in dye solution [1]. Also, different results may be due to the difference in diameter and depth of perforations, number of samples, or duration of observational period [30].

For adequate understanding of results obtained in the current study, it is important to explain the way of dye penetration. Samples that showed dye penetration did not confirm strictly marginal microleakage. In fact, besides the dye detected at the junction of materials and dentin, staining of materials was noted likely due to dye absorption (Figures 4, 5 and 6). Similar results were reported by Tobón-Arroyave et al. [20]. They found that dye penetration in MTA was different in nature than in conventional cements (IRM and Super EBA). When IRM and Super EBA cements were used as apical plug, dye penetration was noted as a circle around the material, between material and dentin. In contrast, in all MTA samples color change was noted in the entire thickness of the material [20]. The reason for these results could be found in MTA structure made of numerous pores and capillaries that could cause more pronounced permeability. It is important however to note that MTA samples in that study had setting time of just 30 minutes before their immersion in dye, therefore results could reflect incomplete setting of material. In the current study, samples were allowed 24 hours setting time before incubation and then after incubation in humid environment for 6 months. This protocol could allow more complete setting and consequently lower dye penetration and absorption.

HA-CS showed the deepest dye penetration and in the majority of samples material disintegration was observed. Since hydroxyapatite is well known for its porous structure and inadequate mechanical properties, the results were somewhat expected. During synthesis HA-CS, calcium silicate was added to hydroxyapatite in order to improve its mechanical properties. Based on the current results it can be noted that additional quantity of calcium silicate (HA:CS=2:1) under the experimental conditions of this study, did not prevent dissolution and leaching of material from the site of application. Literature findings also suggest that calcium phosphate cements do not provide adequate sealing due to their porosity and solubility and in that sense they are inferior to calcium silicate cements [24,25].

It is worth noting that in some MTA and CS samples surface disintegration or dissolution of the outer layer material was noted but still less than in HA-CS samples. In contact with water or phosphate solution, cement releases calcium ions with partial decalcification of calcium silicate hydrate, whereas the expansion of cement after contact with liquid may result in microfractures. All these may constitute an obstacle to long-term stability of the material [13]. However, when interpreting results of an in vitro study, it must be noted that tissue response was absent. Namely, one of the characteristics of the tested bioactive materials in this study is formation of hydroxyapatite on their surface in contact with tissue fluids [3,29], as well as the formation of calcified tissue via calcium silicate or calcium phosphate cements. Therefore, one might expect that in clinical setting material disintegration could be 
self-limiting and hydroxyapatite formed over time could fill the pores within the material and provide chemical bond to dentin contributing to better marginal seal [31].

\section{CONCLUSION}

The lowest marginal microleakage or the best marginal seal was observed in CS and MTA. Microlekage of HA-CS was significantly higher compared to the other two tested materials.

\section{REFERENCES}

1. Torabinejad M, Parirokh M. Mineral trioxide aggregate: a comprehensive literature review - Part II: Leakage and biocompatibility investigations. J Endod. 2010; 36:190-202. [DOI: 10.1016/j.joen.2009.09.010] [PMID: 6380950]

2. Montellano AM, Schwartz SA, Beeson TJ. Contamination of the tooth-colored Mineral trioxide aggregate used as a root-end filling material: a bacterial leakage study. J Endod. 2006; 32:452-5. [DOI: 10.1016/j.joen.2005.07.001] [PMID: 16631847]

3. Gandolfi MG, Taddei P, Tinti A, Prati C. Apatite-forming ability (bioactivity) of ProRoot MTA. Int Endod J. 2010; 43:917-29. [DOI: 10.111./j1365-2591.2010.01.01768.x] [PMID: 20646080]

4. Baek SH, Plenk HJr, Kim S. Periapical tissue responses and cementum regeneration with amalgam, SuperEBA and MTA as root-end filling materials. J Endod. 2005; 31:444-9.

[DOI: 10.1097/01.don.0000148145.81366.a5] [PMID: 15917684]

5. Danesh F, Vahid A, Jahanbani J, Mashhadiabbas F, Arman E. Effect of white Mineral trioxide aggregate compared with biomimetic carbonated apatite on dentine bridge formation and inflammatory response in a dental pulp model. Int Endod J. 2012; 45:26-34. [DOl: 10.1111/j.1365-2591.20011.01941.x] [PMID: 21902703]

6. Da Silva GF, Guerreiro-Tanomaru JM, Sasso-Cerri E, Tanomaru-Filho $M$, Cerri PS. Hostological and histomorphometrical evaluation of furcation perforations filled with MTA, CPM and ZOE. Int Endo J. 2011; 44:100-10.

[DOI: 10.1111/j.1365-2591.2010.01803.x] [PMID: 21039627]

7. Jokanović V, Čolović B, Živković S, Živojinović V, Marković D. Mineral trioxide aggregate as a material of choice in endodontic therapy. Stomatološki glasnik Srbije. 2011; 58:97-107

[DOI: 10.2298/SCS1102097]]

8. Okiji T, Yoshiba K. Reparative dentinogenesis induced by mineral trioxide aggregate: a review from the biological and physicochemical points of view. Int J Dent. 2009; ID464280, 12 pages [DOI: 10.1155/2009464280] [PMID: 20339574]

9. Parirokh M, Torabinejad M. Mineral trioxide aggregate: a comprehensive literature review - Part I: Chemical, physical and antibacterial properties. J Endod. 2010; 36:16-27. [DOl: 10.1016/i.joen.2009.09.006] [PMID: 20003930]

10. Ber BS, Hatton JF, Stewart GP. Chemical modification of ProRoot MTA to improve handling characteristics and decrease setting time. J Endod. 2007; 33:1231-4. [DOI: 10.1016/j.joen.2007.06.012] [PMID: 17889696]

11. Ding SJ, Kao CT, Shie MY, Huang C), Huang TH. The physical and cytological properties of white MTA mixed with $\mathrm{Na} 2 \mathrm{HPO} 4$ as an accelerant. J Endod. 2006; 34:748-51.

[DOI: 10.1016/j.joen.2008.02.041] [PMID: 18498905]

12. Gandolfi MG Taddei P, Siboni F, Modena E, Ciapetti G, Prati C. Development of the foremost light-curable calcium-silicate MTA cement as root-end in oral surgery. Chemical-physical properties, bioactivity and biological behavior. Dent Mat. 2011; 27:134-57. [DOl: 10.1016/..dental.2011.03.011] [PMID: 21529922]

13. Formosa LM, Mallia B, Camilleri J. Mineral trioxide aggregate with anti-washout gel: properties and microstructure. Dent Mater. 2013; 29:294-306.

[DOI: 10.1016/j.dental.2012.11.009] [PMID: 23253552]
14. Saghiri MA, Asgar K, Lotfi M, Garcia-Godoy F. Nanomodification of mineral trioxide aggregate for enhanced physicochemical properties. Int Endod J. 2012; 45:979-88. [DOI: 10.1111/j.1365-2591.2012.02056.x] [PMID: 22519859]

15. Jokanović V. Nanomedicina - najveći izazov 21. veka. Beograd: Data Status; 2012.

16. Jokanović V, Čolović B, Jokanović B, Živković S. Superplastic, quickbonding endodontic mixtures and their hydratation. Int J Appl Ceram Technol. 2015; 12(Suppl 2):E83-E91. [DOI: 10.1111/ijac.12234]

17. Opačić-Galić V, Petrović V, Živković S, Jokanović V, Nikolić B, Knežević-Vučković J, et al. New nanostructural biomaterials based on active silicate systems and hydroxyapatite: characterization and genotoxicity in human peripheral blood lymphocytes. Int Endod J. 2013; 46:506-16. [DOI: 10.1111/iej.12017] [PMID: 23173688]

18. Petrović V, Opačić-Galić V, Živković S, Nikolić B, Danilović V, Miletić $\checkmark$, et al. Biocompatibility of new nanostructural materials based on active silicate systems and hydroxyapatite: in vitro and in vivo study. Int Endo J. 2015; 48:966-75. [DOI: 10.1111/iej12391] [PMID: 25288256]

19. Hashem AAR, Hassanien EE. ProRoot MTA, MTA-Angelus and IRM used to repair large furcation perforations: sealability study. Endod. 2008; 34:59-61. [DOI: 10.1016/j.joen.2007.09.007] [PMID: 18155494]

20. Tobón-Arroyave SI, Restrepo-Pérez MM, Arismendi-Echavarría JA, Velásquez-Restrepo Z, Marin-Botero ML, Garcia-Dorado EC. Ex vivo microscopic assessment of factors affecting the quality of apical seal created by root-end fillings. Int Endod J. 2007; 40:590-602. [DOI: 10.1111/j.1365-2591.2007.01253.x] [PMID: 17511788]

21. Parirokh M, Askarifad S, Mansouri S, Haghdoost AA, Raoof M, Torabinejad M. Effect of phosphate buffer saline on coronal leakage of Mineral trioxide aggregate. J Oral Sci. 2009; 51:187-91. [DOl: 10.1590/1678-775720130023] [PMID: 19550085]

22. De Deus G, Petruccelli V, Gurgel-Filho E, Coutinho-Filho T. MTA versus Portland cement as repair material for furcal perforations: a laboratory study using a polymicrobial leakage model. Int Endod J. 2006; 39:293-8.

[DOI: 10.1111/j.1365-2591.2006.01096.x] [PMID: 16584492]

23. Ferris $D M$, Baumgartner JC. Perforation repair comparing two types of mineral trioxide aggregate. J Endod. 2004; 30:422-4.

[DOI: 10.1097/00004770-2004060000-00011] [PMID: 15167471]

24. Sanghavi T, Shah N, Shah RR. Comparative analysis of sealing ability of Biodentin and calcium phosphate cement against mineral trioxide aggregate (MTA) as a furcal perforation repair material (an in vitro study). NJIRM. 2013; 4:56-60.

25. Tsatsas DV, Meliou HA, Kerezoudis NP. Sealing effectiveness of materials used in furcation perforation in vitro. Int Dent J. 2005; 55:133-41. [DOI: 10.1111/j.1875-595X.2005.tb00310.x] [PMID: 15997963]

26. Wu MK, Kontakiotis EG, Wesselink PR. Decoloration of $1 \%$ methylene blue solution in contact with dental filling materials. J Dent. 1998; 26:585-9. [DOl: 10.1016/s0300-5712(97)000407] [PMID: 9754747]

27. Hawley M, Webb TD, Goodell GG. Effect of varying water-to-powder ratios on the setting expansion of white and grey mineral trioxide aggregate.J Endod. 2010; 36:1377-9. [DOI: 10.1016/j.joen.2010.03.010] [PMID: 20647100]

28. Storm B, Eichmiller FC, Tordik PA, Goodell GG. Setting expansion of gray and white Mineral trioxide aggregate and Portland cement. J Endod. 2008; 34:80-2. [DOI: 10.1016/j.joen.2007.10.006] [PMID: 18155499]

29. Sarkar NK, Caicedo R, Ritwik P, Moiseyeva R, Kawashima I. Physicochemical basis of the biologic properties of mineral trioxide aggregate. J Endod. 2005; 31:97-100. [DOI: 10.1097/01. don.0000133155.04468.41] [PMID: 15671817]

30. De Deus G, Reis C, Brandão C, Fidel S, Fidel RAS. The ability of Portland cement, MTA, and MTA Bio to prevent trough-and-through fluid movement in repaired furcal perforations. J Endod. 2007; 33:1374-7. [DOI: 10.1016/j.joen.2007.07.024] [PMID: 17963967]

31. Gandolfi MG, Parrilli AP, Fini M, Prati C, Dummer PMH. 3D micro$\mathrm{CT}$ analysis of the interface voids associated with Thermafil root fillings used with AH Plus or a flowable MTA sealer. Int Endod J. 2013; 46:253-63. [DOI: 10.1111/j.1365-2591.2012.02124.X] [PMID: 23039158] 


\title{
Ispitivanje marginalne mikropropustljivosti novosintetisanih nanostrukturnih biomaterijala na bazi aktivnih kalcijumsilikatnih sistema i hidroksiapatita
}

\author{
Violeta Petrović1, Vanja Opačić Galić1, Bojan Dželetović1, Vukoman Jokanović , Slavoljub Živković1 \\ 'Univerzitet u Beogradu, Stomatološki fakultet, Klinika za bolesti zuba, Beograd, Srbija; \\ ${ }^{2}$ Institut za nuklearne nauke „Vinča“, Univerzitet u Beogradu, Beograd, Srbija
}

\begin{abstract}
KRATAK SADRŽAJ
Uvod Primena cemenata od kalcijum-silikata u lečenju perforacija korena zuba zasniva se na njihovim izuzetnim biološkim svojstvima i odgovarajućem rubnom zaptivanju. Cilj ovog rada bio je da se testom prodora boje ispita marginalna mikropropustljivost novosintetisanih nanostrukturnih biomaterijala na bazi kalcijumsilikatnih sistema i hidroksiapatita nakon primene materijala u interradiksne perforacije ekstrahovanih zuba.

Materijal i metode rada Ispitivanje je realizovano na 34 ekstrahovana humana molara. Testirani su novosintetisani nanostrukturni materijali: materijal na bazi aktivnih kalcijumsilikatnih sistema (CS) i materijal na bazi hidroksiapatita i aktivnih kalcijumsilikatnih sistema (HA-CS). Kao kontrolni materijal korišćen je komercijalni kalcijumsilikatni cement (MTA Angelus, Londrina, Brazil). Marginalna mikropropustljivost je ispitivana testom prodora boje šest meseci nakon primene materijala u eksperimentalno preparisane interradiksne perforacije na ekstrahovanim humanim molarima. Prodor boje je analiziran svetlosnim mikroskopom na uveličanju od 30 puta metodom kvantifikovanja vizuelnih informacija kompjuterskim programom za obradu slike (Adobe Photoshop CS5 Extended, verzija 12.0x32). Dobijene vrednosti su izražene u milimetrima, a dobijeni rezultati statistički su obrađeni primenom jednofaktorskog testa ANOVA sa Tukijevim (Tukey) post-hoc testom $(\alpha=0,05)$.

Rezultati Najmanji prodor boje izmeren je kod materijala CS $(0,44 \mathrm{~mm})$, dok su nešto veće vrednosti zabeležene kod MTA $(0,54$ $\mathrm{mm})$. Prodor boje kod materijala HA-CS $(2,00 \mathrm{~mm})$ bio je značajno veći u odnosu na materijale CS i MTA $(\mathrm{p}<0,05)$.

Zaključak Najmanja marginalna mikropropustljivost zabeležena je kod materijala CS i bila je komparabilna sa MTA. Mikropropustljivost materijala HA-CS bila je značajno veća u odnosu na materijal CS i kontrolni materijal MTA.

Ključne reči: marginalna mikropropustljivost; kalcijumsilikatni cementi; hidroksiapatit
\end{abstract}

\section{UVOD}

Kvalitetno rubno zaptivanje, odnosno odgovarajuća marginalna adaptacija materijala uz zidove kaviteta, treba da onemogući protok tkivnih tečnosti i posledično bakterijsko mikrocurenje, zbog čega se smatra značajnim faktorom za dugoročan uspeh endodontskog lečenja [1].

Cementi od kalcijum-silikata uvedeni su u endodontsku praksu sredinom devedesetih godina prošlog veka, najpre kao materijali namenjeni lečenju korenskih perforacija i zatvaranju vrha korena zuba nakon apeksne hirurgije. Istraživanja su ukazala na znatno bolje rubno zaptivanje kalcijum-silikata $\mathrm{u}$ odnosu na amalgam i komercijalne cemente na bazi ZOE (Super EBA i IRM cement), koji su obično korišćeni u navedenim indikacijama [1]. Kasnije je utvrđeno da kalcijumsilikatni cementi ostvaruju kvalitetno rubno zaptivanje i u kavitetima koji su kontaminirani krvlju [1,2], da su biokompatibilni [1], bioaktivni [3] i da indukuju regeneraciju čvrstih zubnih tkiva [4, 5] i periodoncijuma [6], zbog čega su njihove indikacije danas značajno proširene [7].

Glavni problem koji otežava kliničku primenu kalcijum-silikata je dugo vreme vezivanja [8]. Inicijalno vezivanje od nekoliko sati nosi rizik od rastvaranja i ispiranja materijala s mesta aplikacije. Za hidrataciju i očvršćavanje materijala neophodna je vlaga, pa se preporučuje da se nakon primene (u periodu inicijalnog vezivanja) materijalu obezbedi eksterna vlaga, što neminovno odlaže završetak endodontskog lečenja [9]. Ranijih godina urađena su brojna istraživanja radi prevazilaženja ovog problema [10-13].

Savremena istraživanja su fokusirana na sintezu i ispitivanja moguće primene nanostrukturnih biomaterijala u sličnim en- dodontskim indikacijama [14]. Nanomaterijale, između ostalog, odlikuje izraženija aktivnost čestica, te posledično brže vezivanje u odnosu na konvencionalne mikrostrukturne materijale [15]. U Institutu za nuklearne nauke u Vinči, prema recepturi Jokanovića i saradnika [16], sintetisana su dva nova biomaterijala: materijal na bazi aktivnih kalcijumsilikatnih sistema (CS) i materijal na bazi hidroksiapatita i aktivnih kalcijumsilikatnih sistema (HA-CS). Nanotehnologijom dobijeni su materijali s inicijalnim vezivanjem od 10 minuta (CS), odnosno 15 minuta (HA-CS). Dosadašnja istraživanja su pokazala da dobijeni materijali imaju slabija genotoksična i citotoksična dejstva, kao i veći osteogeni potencijal u odnosu na komercijalne kalcijumsilikatne cemente $[17,18]$.

Cilj ovog istraživanja bio je da se testom prodora boje ispita marginalna mikropropustljivost materijala CS i HA-CS nakon primene materijala $\mathrm{u}$ interradiksne perforacije ekstahovanih humanih zuba.

\section{MATERIJAL I METODE RADA}

U ovom istraživanju testirani su materijal na bazi kalcijumsilikatnih sistema (CS), materijal na bazi mešavine hidroksiapatita i kalcijumsilikatnih sistema (HA-CS) i kontrolni materijal MTA (MTA Angelus ${ }^{\oplus}$, Londrina, Brazil). Istraživanje je urađeno na 34 humana ekstrahovana maksilarna i mandibularna molara s potpuno razvijenim i nefuzionisanim korenovima. Pristupni kaviteti su preparisani visokoturažnom bušilicom, nakon čega je ručnim K-turpijama (K-files, $V D W G m b H$, Nemačka) utvrđena radna dužina kanala korena zuba, na $1 \mathrm{~mm}$ kraće od anatomskog foramena. Kanali korena su preparisani tehnikom 
crown-down, serijom mašinskih endodontskih instrumenta Bio Race (FKG Dentaire, Swiss Dental Products, Švajcarska). Tokom instrumentacije kanali su ispirani sa $\mathrm{NaOCl}$ u koncentraciji od 0,5\%. Za finalno ispiranje je korišćeno $5 \mathrm{ml}$ desetoprocentne limunske kiseline (tokom jednog minuta) i $5 \mathrm{ml} \mathrm{0,5 \%} \mathrm{NaOCl}$. Nakon sušenja kanali su opturisani monokonom tehnikom uz siler Acroseal (Septodont, Francuska).

Po vezivanju silera, u centru poda pulpne komore, kolenjakom i okruglim borerom veličine \#4, preparisane su interradiksne perforacije tako da je širina perforacija odgovarala promeru borera, dok je dubina zavisila od debljine poda pulpne komore. Posle ispiranja preparisanih kaviteta destilovanom vodom $\mathrm{i}$ sušenja, zubi su metodom slučajnog izbora podeljeni u tri eksperimentalne grupe, a perforacije zatvorene test materijalima CS, HA-CS i MTA ( $\mathrm{n}=10)$. Pozitivnu kontrolnu grupu činila su dva zuba kod kojih perforacije nisu zatvorene materijalima, a negativnu dva zuba bez perforacija.

Pre primene ispitanih materijala zubi su do nivoa gleđnocementne granice postavljeni u sunđer natopljen veštačkom tkivnom tečnošću - Henkovim uravnoteženim slanim rastvorom (engl. Hank's balanced salt solution - HBSS). Materijali su zamešani sa destilovanom vodom u odnosu 3:1 i u kavitete kondenzovani nabijačima. Preko materijala je postavljena vlažna vatica, a zatim su zubi inkubirani na $37^{\circ} \mathrm{C}$ tokom 24 časa. Po vezivanju materijala pristupni kaviteti su konačno zatvoreni kompozitom, a zubi u natopljenom sunđeru inkubirani na $37^{\circ} \mathrm{C}$ narednih šest meseci.

Posle šest meseci marginalna mikropropustljivost je ispitivana metodom pasivnog prodora boje. Zubi su premazani sa dva sloja laka, osim u predelu materijala u furkaciji ( $1 \mathrm{~mm}$ oko materijala) i potopljeni u pedesetoprocentni rastvor srebro-nitrata $\left(\mathrm{AgNO}_{3}\right)$ tokom dva časa. Nakon kratkog ispiranja zubi su ostavljeni u fotografskom razvijaču narednih šest sati. Zatim su longitudinalno sečeni u predelu interradiksnih perforacija dijamantskim diskom debljine $0,7 \mathrm{~mm}$, linearnom preciznom testerom sa vodenim hlađenjem (Isomet testera 4000, Buehler, Lake Bluff, IL, SAD). Prodor boje između materijala i zidova kaviteta je analiziran svetlosnim mikroskopom i fotografisan pri uveličanju od 30 puta. Dubina prodora boje je merena metodom kvantifikovanja vizuelnih informacija kompjuterskim programom za obradu slike (Adobe Photoshop CS5 Extended, verzija 12.0x32). Dobijene vrednosti su izražene u milimetrima, a rezultati statistički obrađeni primenom jednofaktorskog testa ANOVA sa Tukijevim (Tukey) post-hoc testom. Nivo značajnosti utvrđen je na $\alpha=0,05$.

\section{REZULTATI}

Najmanji prodor boje izmeren je kod materijala CS $(0,44 \pm 0,54$ $\mathrm{mm}$ ) (Slika 1). Slične vrednosti izmerene su za materijal MTA $(0,54 \pm 0,76 \mathrm{~mm})$ (Slika 2). Najveći prodor boje zabeležen je kod

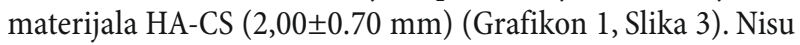
uočene statistički značajne razlike u marginalnom prodoru boje između materijala CS i MTA. Kod materijala HA-CS izmerene vrednosti prodora boje bile su statistički značajno veće u odnosu na prodor boje kod materijala CS i MTA $(\mathrm{p}<0,05)$.

Osim prodora boje, na spoju materijala i zubnih struktura uočeno je prebojavanje testiranog materijala primenjenog u veštački formirane interradiksne perforacije (Slike 4, 5 i 6).

\section{DISKUSIJA}

Za procenu marginalne mikropropustljivosti materijala u studijama in vitro obično se koriste metode prodora boje $[19,20]$, prodora bakterija [21] i filtracije tečnosti [22]. U ovom istraživanju za procenu mikropropustljivosti je primenjena metoda prodora boje, koja je zbog svoje jednostavnosti korišćena u velikom broju istraživanja [19, 20, 23, 24, 25]. Glavni nedostatak ove metode je, međutim, u tome što je veličina molekula boja koje se obično koriste manja od veličine bakterija [19]. Kod materijala kod kojih se beleži prodor malih molekula boje može se očekivati izostanak mikrocurenja većih molekula, poput bakterija i njihovih proizvoda [1].

Prilikom odabira boje za procenu marginalne propustljivosti uzeta je u obzir hemijska priroda materijala koji se ispituje. Naime, $\mathrm{Vu}(W u)$ i saradnici [26] su ustanovili da je metilen plavo nestabilno u prisustvu alkalnih supstanci, što dovodi do njegovog obezbojavanja. Kako je kalcijum-hidroksid glavna hemijska smesa koja se oslobađa iz MTA, upotreba metilen plavog prilikom ispitivanja MTA i drugih materijala sličnog hemijskog sastava bi, usled diskoloracije boje, mogla dovesti do nepouzdanih rezultata. Rastvor srebro-nitrata je stabilan u prisustvu materijala visoke vrednosti $\mathrm{pH}$, a čestice srebra imaju veliku molekularnu masu, što su i bili razlozi za njegovu primenu u ovom istraživanju [25].

Marginalna mikropropustljivost je ispitivana nakon primene testiranih materijala u eksperimentalno preparisane interradiksne perforacije na ekstrahovanim zubima. Tokom eksperimentalnog perioda zubi su čuvani u inkubatoru, u sunđeru natopljenom veštačkom tkivnom tečnošću, kako bi se što bliže simulirali klinički uslovi [21]. U ovom istraživanju merena je najdublja tačka prodora boje uz napomenu da longitudinalnim sečenjem zuba, koje se obično primenjuje, nije moguće precizno utvrditi u kojem delu kaviteta je boja najdublje prodrla. Zbog toga se prodor boje pri određivanju mikropropustljivosti u uslovima in vitro ne može direktno uporediti s kompleksnim mikrocurenjem u uslovima in vivo, ali se može smatrati pokazateljem moguće propustljivosti materijala u kliničkim uslovima [20].

Najmanji prodor boje u ovom istraživanju uočen je kod materijala CS. Vrednosti prodora boje kod MTA bile su nešto veće, ali bez statistički značajne razlike u odnosu na CS. S obzirom na to da su CS i MTA materijali sličnog hemijskog sastava, i njihove fizičke osobine mogu biti slične. Dobro rubno zaptivanje kalcijumsilikatnih cementa se povezuje sa blagom ekspanzijom cementa prilikom vezivanja $[27,28]$, odnosno bioaktivnom prirodom i stvaranjem hidroksiapatita na površini materijala $u$ kontaktu s fosfatima iz tkivnih tečnosti [29].

Ipak, različitim metodama ispitivanja mikropropustljivosti uočeno je da MTA i slični kalcijumsilikatni cementi nemaju sposobnost apsolutnog hermetičkog zaptivanja [21, 22, 25, 30], što je u skladu s rezultatima ovog istraživanja. U grupi uzoraka ispunjenih materijalom CS izmerene su nešto manje vrednosti prodora boje u odnosu na uzorke ispunjene sa MTA, ali je prodor boje uočen u većem broju uzoraka nego u MTA grupi. Izmerene vrednosti prodora boje u MTA grupi bile su vrlo različite, a dobijeni rezultati su u skladu s nalazima De Deusa (De Deus) i saradnika [30], koji su, ispitujući marginalnu mikropropustljivost različitih kalcijumsilikatnih cemenata (PC, MTA Angelus i MTA Bio), pisali o vrlo varijabilnim rezultatima unutar grupa. Isti autori su mikropropustljivost otkrili u svim uzorcima, ali bez 
statistički značajnih razlika u pogledu propustljivosti različitih kalcijumsilikatnih cemenata [30]. Suprotno tome, Hašem (Hashem) i saradnici [19] su uočili razlike u propustljivosti različitih komercijalnih kalcijum-silikata, smatrajući da različit hemijski sastav i različita brzina vezivanja cemenata može imati ulogu $\mathrm{u}$ adaptaciji materijala za zidove kaviteta. I studije u kojima je propustljivost kalcijum-silikatnih cemenata ispitana metodom prodora bakterija takođe su ukazale na različite rezultate. Tako su Montelano (Montelano) i saradnici [2] najizraženije mikrocurenje zabeležili u prvim danima primene materijala, dok su Pariroh (Parirokh) i saradnici [21] otkrili prodor bakterija značajno kasnije (između 39 i 73 dana eksperimenta), ističući pozitivan uticaj fosfatnog rastvora na prianjanje materijala.

Uopšteno posmatrajući, pregledom literature uočava se nekonzistentnost rezultata u pogledu dobijenih vrednosti propustljivosti kalcijumsilikatnih cemenata u okviru različitih metoda ispitivanja. Iz dosadašnjih istraživanja može se zaključiti da brojni faktori utiču na mikropropustljivost MTA: od vrste boje, $\mathrm{pH}$ vrednosti boje, uslova čuvanja uzoraka pre eksperimenta, odnosno vremena vezivanja uzoraka materijala pre njihovog potapanja u boju [1]. Takođe, različiti rezultati mogu biti posledica i razlika u prečniku i dubini perforacija, broja uzoraka, odnosno razlika u trajanju opservacionog perioda [30].

Za razumevanje dobijenih rezultata u ovom istraživanju značajno je napomenuti i način prodora boje. U uzorcima u kojima je uočen prodor boje ne može se govoriti o striktno marginalnoj mikropropustljivosti. Naime, osim boje ustanovljene na spoju materijala i zubnih struktura, uočeno je prebojavanje samog materijala koje je verovatno posledica apsorpcije boje (Slike 4, 5 i 6). Do sličnih rezultata došli su i Tobon-Arojave (Tobón-Arroyave) i saradnici [20], koji su utvrdili da se način prodora boje kod MTA razlikuje od prodora boje kod konvencionalnih cemenata (IRM i Super EBA). Ispitujući mikropropustljivost materijala nakon njihove primene u formi apeksnog čepa, prodor boje kod IRM i Super EBA cementa uočen je kružno oko materijala, odnosno između materijala i dentina kanala korena. Nasuprot tome, u svim uzorcima sa MTA uočena je apsorpcija boje čitavom debljinom materija [20]. Razlog ovakvih rezultata može biti sama struktura cementa, koji su izgrađeni od brojnih pora i kapilara koji su mogli dovesti do izraženije propustljivosti. Važno je, međutim, napomenuti da su se u pomenutom istraživanju uzorci MTA vezivali samo 30 minuta pre njihovog potapanja u boju, te dobijeni rezultati mogu biti i posledica nepotpunog vezivanja materijala. $U$ ovom istraživanju uzorci materijala su se vezivali 24 časa i nakon toga su inkubirani u vlažnoj sredini još šest meseci. Ovakav protokol je mogao dovesti do potpunijeg vezivanja i posledično manjeg prodora, odnosno manjeg upijanja boje.

Kod materijala HA-CS izmeren je najveći prodor boje, a u većini uzoraka je uočena i izražena dezintegracija materijala. $S$ obzirom na to da je hidroksiapatit dobro poznat po poroznoj strukturi i neodgovarajućim mehaničkim svojstvima, dobijeni rezultati su donekle očekivani. Prilikom sinteze materijala HACS, kalcijumsilikatni sistem je dodat hidroksiapatitu upravo radi poboljšanja njegovih mehaničkih svojstava. Na osnovu dobijenih rezultata može se zaključiti da dodata količina kalcijumsilikata (HA:CS, 2:1) u eksperimentalnim uslovima ove studije nije sprečila rastvaranje i ispiranje materijala s mesta aplikacije. U literaturi je potvrđeno da su kalcijumfosfatni cementi, zbog svoje poroznosti i posledične rastvorljivosti, materijali sa neodgovarajućim rubnim zaptivanjem, te u tom pogledu značajno manje efikasni od cemenata na bazi kalcijum-silikata [24,25].

Važno je napomenuti da je i u pojedinim uzorcima sa MTA i materijalom CS uočena površinska dezintegracija, odnosno rastvaranje spoljašnjeg sloja materijala, ali u znatno manjoj meri u odnosu na materijal HA-CS. U kontaktu s vodom ili fosfatnim rastvorom cement otpušta kalcijumove jone sa delimičnom dekalcifikacijom kalcijumsilikatnog hidrata, a ekspanzija cementa posle kontakta s tečnošću može izazvati mikropukotine, što sve zajedno može predstavljati prepreku dugoročnoj stabilnosti materijala [13]. Ipak, prilikom tumačenja rezultata istraživanja u uslovima in vitro mora se imati u vidu da tokom ovih ispitivanja izostaje kompleksan odgovor tkiva. Naime, jedna od odlika bioaktivnih materijala ispitanih u ovom istraživanju jeste stvaranje hidroksiapatita na njihovoj površini u kontaktu s tkivnim tečnostima [3,29], kao i stvaranje kalcifikovanog tkiva preko kalcijumsilikatnih, odnosno kalcijumfosfatnih cemenata. Stoga bi se moglo očekivati da bi u kliničkim uslovima dezintegracija materijala bila samoograničavajuća i da bi hidroksiapatit, formiran u funkciji vremena, mogao ispuniti pore unutar materijala i obezbediti hemijsku vezu sa dentinom i time doprineti kvalitetnijem rubnom zaptivanju [31].

\section{ZAKLJUČAK}

Najmanja marginalna mikropropustljivost, odnosno najbolje rubno zaptivanje zabeleženo je kod materijala CS i bilo je slično sa MTA. Mikropropustljivost materijala HA-CS bila je značajno veća u odnosu na materijal CS i kontrolni materijal MTA. 